\title{
The Determinants of Access to Sanitation: The Role of Human Rights and the Challenges of Measurement
}

\author{
Rebecca Schiel ${ }^{1,2}\left(\mathbb{C}\right.$, Bruce M. Wilson ${ }^{1,2, *}$ and Malcolm Langford ${ }^{2,3}(\mathbb{C}$ \\ 1 School of Politics, Security, and International Affairs, University of Central Florida, Orlando, FL 32816, USA; \\ rebecca.schiel@ucf.edu \\ 2 Chr. Michelsen Institute, 5003 Bergen, Norway; malcolm.langford@jus.uio.no \\ 3 Department of Public and International Law, University of Oslo, 0130 Oslo, Norway \\ * Correspondence: bruce.wilson@ucf.edu
}

Citation: Schiel, R.; Wilson, B.M.; Langford, M. The Determinants of Access to Sanitation: The Role of Human Rights and the Challenges of Measurement. Water 2021, 13, 1676. https://doi.org/10.3390/w13121676

Academic Editor: Julio Berbel

Received: 29 April 2021

Accepted: 4 June 2021

Published: 17 June 2021

Publisher's Note: MDPI stays neutral with regard to jurisdictional claims in published maps and institutional affiliations.

Copyright: (c) 2021 by the authors. Licensee MDPI, Basel, Switzerland. This article is an open access article distributed under the terms and conditions of the Creative Commons Attribution (CC BY) license (https:// creativecommons.org/licenses/by/ $4.0 /)$.

\begin{abstract}
Ten years after the United Nation's recognition of the human right to water and sanitation (HRtWS), little is understood about how these right impacts access to sanitation. There is limited identification of the mechanisms responsible for improvements in sanitation, including the international and constitutional recognition of rights to sanitation and water. We examine a core reason for the lack of progress in this field: data quality. Examining data availability and quality on measures of access to sanitation, we arrive at three findings: (1) where data are widely available, measures are not in line with the Sustainable Development Goal (SDG) targets, revealing little about changes in sanitation access; (2) data concerning safe sanitation are missing in more country-year observations than not; and (3) data are missing in the largest proportions from the poorest states and those most in need of progress on sanitation. Nonetheless, we present two regression analyses to determine what effect rights recognition has on improvements in sanitation access. First, the available data are too limited to analyze progress toward meeting SDGs related to sanitation globally, and especially in regions most urgently needing improvements. Second, utilizing more widely available data, we find that rights seem to have little impact on access.
\end{abstract}

Keywords: sanitation; water; human rights; sustainable development goals; data quality; data availability

\section{Introduction}

The 2010 UN Declaration on the Human Right to Water and Sanitation (HRtWS) marked the end of a long road toward the international legal acceptance of what are arguably two of the most basic human rights [1]. The process that led to this ultimate formal recognition began with the 1977 Mara del Plata Water Conference, where water was recognized as a right for the first time [2]. Later, sanitation was first recognized, implicitly or indirectly, as a right in 1979 at the Convention on the Elimination of All Forms of Discrimination Against Women (CEDAW) [3]. In the subsequent years, several attempts to move forward this legalization occurred, including General Comment No. 15 in 2002, wherein the 1966 International Covenant on Economic, Social, and Cultural Rights (ICESCR) was interpreted by its monitoring committee to include the right to water (although not sanitation) [4]. Subsequently, the right to water and sanitation was incorporated in a greater number of constitutions [5] and this, together with the appointment of a UN special rapporteur, helped spur the eventual formal inclusion of both rights in the UN's catalogue of rights [6].

The passage of time since the completion of this long road towards international recognition of the human right to water and sanitation prompts two questions. First, has access to water and sanitation improved in the decade since its recognition? And second, what role, if any, do human rights play in achieving improved water and sanitation access? While multiple studies have assessed these questions, largely focusing on water access and 
quality dimensions, the literature has failed to meaningfully assess the role of rights in the improvement of access to safely managed sanitation. This is unfortunate, as pointed out by Patunru, because sanitation access has some of the most far-reaching effects on health outcomes, even when compared with water access [7]. Indeed, some estimates suggest that as much as $6.6 \%$ of the global burden of disease is directly attributable to poor sanitation and water quality [8]. The economic effects are also considerable: a 1991 Peruvian cholera outbreak killed 3000 people and resulted in economic costs that were far greater than the preceding decade's total investment in water and sanitation projects [9]. Further, gains in sanitation between 1990 and 2015 are being eroded in developing states by rapid population growth and urbanization despite the inclusion of an ambitious Sustainable Development Goal (SDG) on universal access to sanitation [10]. In short, there is an urgent need to understand the current sanitation context and to highlight the precise mechanisms at work leading to safe sanitation access. However, progress on both research agendas remains hampered, largely by poor data quality and availability concerning access to safely managed sanitation.

Our contribution therefore focuses on three? issues in the study of sanitation. First, what role, if any, do human rights play in improving access to sanitation? Second, what accounts for the lack of understanding of the mechanisms responsible for improving sanitation access? Related, are available data capable of illustrating these mechanisms?

We begin with a review of progress on improving access to sanitation through the lens of the last two iterations of global development goals. This is followed by a review of literature concerning the determinants of access to sanitation and the impact of human rights, especially the human right to sanitation. We then provide an in-depth look at the data available to study sanitation and the potential impact of human rights recognition. This includes a discussion of the available measures, the degree of missing data, and the degree to which the missing data may introduce bias into assessments. Next, we describe our empirical strategy, utilizing the most widely available measures of sanitation access to examine two questions: the extent to which rights play a role in sanitation outcomes and the degree to which the available data can produce meaningful results. We conclude with remarks concerning a proposed research agenda examining sanitation access and progress.

\section{Sanitation, Access, \& Human Rights: A Review}

\subsection{Progress on Sanitation}

Sanitation was initially excluded from the 2001 Millennium Development Goals (MDGs) that were developed based on the 2000 Millennium Declaration. However, during the World Summit in Johannesburg in 2002, sanitation was included. States set a target of halving the number of individuals lacking access to basic sanitation ("facilities that ensure hygienic sanitation that separates human excreta from human contact"), as part of Goal 7 (Target C) regarding environmental sustainability, for the period 1990 to 2015 [11].

The Joint Monitoring Programme (JMP) tracked progress on this goal, focusing on improved sanitation as a proxy for basic access. A 2015 report noted that the target had not been met. The proportion of individuals with access to basic sanitation had only increased from $54 \%$ to $68 \%$ (falling well short of the targeted $77 \%$ ). As of 2015 , the target was missed by over 700 million, with more than 2.4 billion people lacking access to the higher threshold of safe sanitation [12]. While the MDGs were established in 2000, the baseline year was set at 1990, meaning that all progress toward this goal beginning in 1990 would be considered in assessments on progress through 2015. Between 1990 and 2015, more than 2.1 billion people gained access to improved sanitation, representing $58 \%$ of the global population. Indeed, while some states made considerable progress toward achieving the initial MDG sanitation target, many states in the developing world continued to lag proportionally behind [13].

The new Sustainable Development Goals (SDGs), with a target date of 2030, identified even loftier goals-universal access for "safely managed" sanitation, with the JMP reporting progress through 2017 [14]. The most recent reports suggest that only about $45 \%$ of the 
global population have access to such safe sanitation [15]. While low, there are reasons to question this figure. Indeed, as Cumming and colleagues point out, most assessments of progress on water and sanitation targets compare community-level water with household sanitation. Once correcting for this, the authors assert that the global water deficit is as high as that of sanitation [8]. Further, with the change in targets from basic (improved) sanitation to safely managed sanitation, data availability has not improved to accurately assess progress. While the measure relied on for the MDG assessments (improved sanitation) is widely available temporally (1990-2017), the measure recording safely managed sanitation suffers from both high degrees of missing data and considerable bias regionally and in terms of development. We therefore question the extent to which findings concerning improvements in safely managed sanitation can be generalized.

The sanitation targets set out by the MDGs and SDGs thus vary in their ambition. MDG targets identified, for example, "improved sanitation" whereas the SDGs now identifies "safely managed sanitation". The MDG target (improved sanitation) was defined as sanitation that is connected to "a public sewer or septic system, access to a pour-flush latrine, a simple pit latrine, or a ventilated improved pit latrine" [16]. Alternatively, with the new SDG target of safely managed sanitation, the aim is to ensure a sanitation system where "excreta is safely disposed of in situ or treated off-site" [17]. While we should certainly expect the goal posts to move as progress occurs, data quality and availability must improve for accurate assessments of progress to occur. Additionally, while progress was recorded on improved sanitation access, the original goal was not met: By 2017, over half of the world's population still lacked access to safely managed sanitation and almost half had no access to even basic sanitation (i.e., improved, the closest current measure to improved sanitation utilized in the MDGs) [18]. In short, development goals shifted their target from improved sanitation to safely managed sanitation without having reached the initial goal. Further, progress on development goals related to sanitation is currently gauged utilizing measures that suffer from both poor availability and quality. We now turn to what might explain (lack of) access to sanitation.

\subsection{Determinants of Access to Sanitation}

The oft-repeated statement that 'sanitation is the poor cousin of water' is applicable to the state of the research literature. Examining eleven extant studies on sanitation, scholars have asserted that several factors are associated with improved sanitation. First, both subnational and cross-country studies show that wealth is highly correlated with improved sanitation access [10,19-22]. Other studies assert a reverse relationship where sanitation provides a foundation for economic growth [23]. Second, sanitation access is highly correlated with geographical location, with trends present in both geography and urban/rural locations. Third, aid is correlated with improved sanitation access in developing states when it is targeted broadly, and not just for water and sanitation alone [24]. Finally, one study examining the mechanisms through which sanitation access is improved suggests that community-led total sanitation (CLST) programs can result in sanitation improvements [25]. This includes a process where local stakeholders are made aware of the benefits of sanitation improvements, thus increasing their willingness to "buy into" improvement programs. However, beyond factors including development, location, and aid, little is understood about the factors that improve sanitation access.

Moreover, examining the literature concerning sanitation, it is unsurprising that we have learned little about how progress on sanitation access can be achieved. Of the eleven examined recent studies on sanitation, all but one utilized measures of basic or improved sanitation [25]. This is again unsurprising, as we illustrate below, given the quantity and quality of the available data concerning safely managed sanitation access. However, utilization of these data limits our ability to understand progress on adequate levels of access, which are central to both the Sustainable Development Goals and, as we illustrate, progressive realization of the human right to sanitation-to which we now turn. 


\subsection{Access to Sanitation as a Human Right}

The movement to recognize the human right to sanitation came much later than similar movements to advance water as a human right. The drive toward recognition started in the late 1990s as part of a broader human rights-based approach to sanitation. The drive was led by development and health practitioners, rather than by human rights organizations $[26,27]$. These practitioners stressed the benefits of a "human rights approach to sanitation" that could hold to "account those responsible", promote "information sharing and genuine participation in decision making," give attention to "vulnerable and marginalised groups," provide "minimum" universal requirements and create a rights-responsive framework for public policy development and resource allocation [28]. These claims are often advanced for developing countries, but also have clear relevance in many wealthier countries where access to sanitation, especially for marginalized groups, remains far from universal.

The first time the right to sanitation was formally recognized in an international document was in the 1992 Dublin Principles that stated, "it is vital to recognize first the basic right of all human beings to have access to clean water and sanitation at an affordable price" [29]. In 1994, 177 countries endorsed a Programme of Action at the Cairo Conference on Population and Development to recognize all individuals' "right to an adequate standard of living for themselves and their families, including adequate food, clothing, housing, water and sanitation." The UN-Habitat Global Plan of Action (1996) contained identical language, whereas the Johannesburg Declaration (2002) was more circumspect and referred to dignity rather than rights [30,31].

The question then arose whether the right to sanitation was actually a human right, and in particular if it could be derived from the human right to adequate standard of living, codified in Article 11 of the ICESCR. However, after a long debate the UN Committee on Economic, Social and Cultural Rights rejected such a legal interpretation. In 2002 it found that it could only apply to the human right to right to water [32] as there was insufficient international and national practice for deriving a human right to sanitation. Nonetheless, the issue persisted and was steadily advanced in the UN human rights system, especially in the UN Human Rights Council and the work of the Independent Expert [6].

In 2010, the matter of codification of a right to sanitation was finally resolved when the UN General Assembly recognized "the right to safe and clean drinking water and sanitation as a human right that is essential for the full enjoyment of life and all human rights" [32]. While no states voted against the resolution, 41 states abstained and just 122 countries voted in favor. Most abstaining states, though, noted that their objection was not about the substance of the resolution, but the procedure and that the vote was premature as it was simultaneously being addressed by the UN Human Rights Council. The states that abstained from the vote or were recorded as absent were largely the most developed states. Indeed, basic sanitation rates among states that voted for the HRtWS are more than four percentage points lower than those that did not affirm. This gap is even greater regarding safe sanitation, where states that voted to affirm rank, on average, 20 percentage points below those that did not. While most of these states expressed only procedural opposition, some states were substantively opposed [33].

In September 2010, the UN Human Rights Council, whose members included many of the states that had abstained in the earlier General Assembly vote, affirmed the recognition of the right to sanitation without a vote and thus largely resolved the previous division [32]. The General Assembly's recognition, and subsequent UN Human Rights Council endorsement, appears to have largely settled the matter in international law and the legal foundations of the right. The right to sanitation could be derived from the right to adequate standard of living and was related to the right to health [32]. Simultaneously, the CESCR declared that the right to sanitation could also be drawn from those existing rights contained in the ICESCR [34].

The CESCR, curiously, did not comment on the content of the right as it had done with water. It simply expressed the view that the right to sanitation requires "full recognition by States parties in compliance with the human rights principles related to non-discrimination, 
gender equality, participation and accountability" [34]. The question of content was essentially left to the office of the newly Special Rapporteur on the Human Rights to Water and Sanitation as well as scholarship and practice. According to a report of the UN Special Rapporteur, its main features are as follows: Recognition of the right entails a duty of respect (states must refrain from acts or measures that "threaten or deny individuals or communities existing access to sanitation"); a duty to protect (states must act to ensure nonstate actors respect the right); and a duty to fulfil (states must take "deliberate, concrete and targeted steps" and thereby move as "expeditiously and effectively as possible" towards "ensuring access to safe, affordable and acceptable sanitation for all, which provides privacy and dignity"[35]. Achieving this required several steps. These included "developing and adopting a national sanitation strategy and plan of action", ensuring "full participation" of individuals and communities in policy development and implementation, and providing "effective judicial or other appropriate remedies"[35].

At the national level, a growing number of states subsequently recognized the human right to sanitation: The right has progressively been included in many countries' constitutions, national laws, and policy instruments, and in some regional political declarations (for example, the South Asian Conference on Sanitation in 2008 and 2011) [36].

Despite this breakthrough in the recognition of a self-standing right to sanitation, human rights related to sanitation make up a broad category. Already in CESCR general comments on housing, health, and water, provision of adequate sanitation was included as an important category $[4,37,38]$. The right to housing includes "sanitation and washing facilities" and "site drainage" and sanitation is listed as one of the underlying determinants of health [35]. Sanitation was part of the CESCR's General Comment No. 15 on the Right to Water that includes water for personal hygiene and sanitation [4]. The Committee emphasized further that access to sanitation was both "fundamental for human dignity and privacy" and a "principal mechanism for protecting the quality of drinking water supplies and resources" [4]. The progressive "extension of safe sanitation services" was also expressed as a state responsibility [4]. The UN Special Rapporteur on water and sanitation also highlighted the broad significance of sanitation for human rights including life, physical security, prohibition of inhuman or degrading treatment, gender equality, education, work, and decent working conditions [35].

In our analysis on the impact of rights, we have therefore chosen to focus on three core human rights relevant to improving access to sanitation: the right to sanitation, the right to water, and the right to health. However, while all are now recognized internationally, it is relevant to examine rights at the national level, including those that have been enshrined within state constitutions. It may be that double recognition enhances impact.

Beginning with sanitation, only 15 states, largely located in Latin America, include either an aspirational or judicially enforceable right to sanitation [37]. Unlike affirmative votes for the UN declaration, the average of basic sanitation among this group of states is slightly higher than those states lacking a right to sanitation $(<3 \%)$. However, little can be gleaned by this figure given the exceedingly small number of states with a constitutional right to sanitation: just 26 states include the right to water in their constitutions, either aspirational or judicially enforceable. This figure is, notably, more than double the number of countries with a right to sanitation. The states making up this group are largely those that have a right to sanitation with the addition of several African and European states. Finally, the right to health is considerably more common with 85 states enshrining either an aspirational or judiciable right in their constitution. Thus, enshrining a right related to sanitation, even broadly, is not a common occurrence. While this alone should temper our expectations concerning the ability to recognize effects of rights in a large- $\mathrm{N}$ analysis, the much larger issue concerns sanitation data quality and availability. The discussion now turns to these respective points of impact and measurement. 


\subsection{Impact of Human Rights}

Considering the recent ten-year anniversary of the adoption of the UN declaration, it is pertinent to ask what role, if any, do rights have in improving access to sanitation? Human rights, broadly speaking, are widely debated in their utility and efficacy. The practical critique of a human rights-based approach is that it adds little to help overcome the real world challenges of expanding access and that it presupposes the existence of high literacy levels across the population and robust public institutions including courts and bureaucracies $[37,38]$. A more conservative critique of the human rights-based approach is that it could lead to increased conflict among users, delivery organizations, and governments. It is argued that it could also lead to the inculcation of a dependency culture and users' general reluctance participate in infrastructure development and its management and might just create a new layer of bureaucracy $[39,40]$. A more radical critique is that human rights-based approaches lack transformative and emancipatory power and that there is an intrinsic danger that the recourse to law and lawyers will result in a minimization and weakening of political demands and organization [41,42].

Alternatively, others suggest that human rights are both necessary and effective, delineating a causal link between the adoption of rights and respect for such rights [43]. Proponents of this school of thought point to gains in living standards globally since the adoption of landmark human rights [44]. More concretely, the ways in which the legal recognition of rights are expected to work can be organized into three mechanisms: material, political, and symbolic [45]. Briefly, rights might work through a material mechanism whereby a right is enshrined in law and made enforceable, and thus subject to challenge, through courts. Rights may also work through a political mechanism whereby the adoption of a right into a domestic constitution signifies the inflection of such values in domestic politics. The right then acts as a reminder to politicians of the previously defined imperative to respect it and provides a political resource in policy discussions. Finally, rights may be effective through their symbolic power. In this case, we should expect rights to change social meanings and behavior related to the right [46].

The research on whether the creation of a human right to sanitation or sanitationrelated rights has a significant impact is limited. Langford, Bartram, and Roaf (2017) reviewed several qualitative studies on the impact of legal recognition of the right to sanitation and related rights [5]. First, a 2011 study of four countries where the right to sanitation had been recognized finds that it was too early to draw definitive conclusions concerning improved access to sanitation derived from the state's recognition of the right to sanitation. The study notes, though, that the "formal recognition" of the right "can be an important accelerator if it is combined with a range of political drivers which build an enabling environment and support inclusive implementation towards rights fulfilment" [47]. Second, regional legal recognition has had some effects. For example, after the Third South Asian Conference on Sanitation, which recognized a right to sanitation, civil society organizations successfully lobbied governments to make more significant policy and funding commitments and to prioritize vulnerable and marginalized groups. In the case of Nepal, for example, a new Master Plan for Sanitation and Hygiene increased the sanitation budget almost twofold [48]. Third, international development officials have indicated the symbolic power of right to sanitation. For example, the EU through its ACP-EU Water Facility has supported water and sanitation infrastructure and supply projects, particularly in marginalized areas and focusing on the neediest people. However, it often struggled to ensure that partner countries requested support for sanitation as these countries tended to request support of water projects only. Officials indicated that they had used the right to sanitation as a lever to encourage partner states to seek support for sanitation, emphasising the legal obligation [49].

Finally, court cases from India, Pakistan, and South Africa show surprising possible impacts of the right to sanitation while also containing variable outcomes in material implementation. In India in 1980, the Supreme Court found in the case of Ratlam v. Shri Vardhich that a municipality's failure to provide toilets and drainage for informal 
settlements was an assault on decency and dignity as it violated the Municipality Act and threatened human health and by implication, human rights [50]. Indian courts have also constitutionalized statutory obligations to direct municipalities to address untreated water drainage [51]. Similarly, in Pakistan, the Supreme Court held in Human Rights Case No. 9 that the reliance on open storm water drains to dispose of raw sewage was hazardous and the Court ordered the situation remedied [52]. As a result of the court order, pipes were repaired and an underground reservoir was constructed [53-55].

In 2011 in South Africa, opposition parties contesting the local elections labelled them the "toilet election" focusing on the failure of the ANC local government in Moqhaka to deal with the sanitation issue of 1600 unenclosed toilets in the informal settlements. "Politicians, journalists and the electorate seemed stunned by the sight of these open toilets" as matters of "dignity and privacy, so central to South Africa's constitution, seemed to be rendered meaningless by images of toilets without walls" [56]. In the Western Cape, the residents of the informal settlement that started the debate took the matter to the High Court [57]. The Court decided that existing legislation did not justify the building of one toilet for every five families during the upgrading of the informal settlement. Moreover, the Court held that that open toilets provided on this basis "must provide for the safety and privacy of the users and be compliant with the fundamental rights guaranteed in the Constitution", and if not would be inconsistent with the right to housing and rights to privacy and dignity in the constitution" [58].

The case thus generated a national dialogue while also providing some concrete material outcomes, with media reports indicating that the community gained more dignified access to sanitation [56]. At the same time, Robins questioned the magnitude of its effect: the "politics of the spectacle also obscured the more mundane indignities, health hazards and forms of structural violence that millions of poor people have to endure on a daily basis" [57]. Nonetheless, when litigation is repeated it may be possible to generate further political and material impacts. For example, after the claims of residents of the Harry Gwala informal settlement for temporary sanitation were rejected in the High Court and Constitutional Court (only gaining successful orders for water taps, refuse collection, and accelerated upgrading [58-60]), the municipality eventually supplied more than the 1 toilet for 10 families it originally offered as a settlement in court [61]. Moreover, other local communities viewed the decision as applicable to their similar situation and have explicitly used it in their negotiations with local governments [59].

These case studies provide a fine-grained and conditional perspective on how legal recognition of sanitation-related human rights can impact access. We now turn to the available, albeit limited, data to analyze whether these effects exist more broadly.

\section{Assessing Available Sanitation Data}

Available sanitation data are comprised of the following measures: open defecation (SDG goal \#6 seeks its eradication), basic sanitation, safe sanitation, and basic handwashing. These data are derived from the Joint Monitoring Programme by UNICEF and the WHO [62]. Each of these measures then records the percentage of the state's population having access to the sanitation category, apart from open defecation, which reports the percentage of the population engaging in the practice. Table 1 provides descriptive statistics on each of these measures including the percentage of missing data.

Table 1. Descriptive Statistics.

\begin{tabular}{ccccccc}
\hline Variable & Obs. & Mean (\%) & Std. Dev. & Min (\%) & Max (\%) & Missing (\%) \\
\hline Open Defecation & 3371 & 10.921 & 17.713 & 0 & 84.59 & 9.43 \\
Basic Sanitation & 3325 & 70.374 & 29.913 & 6.6 & 100 & 10.67 \\
Safe Sanitation & 1571 & 63.346 & 30.307 & 3.163 & 100 & 57.79 \\
Basic Handwashing & 905 & 44.354 & 33.083 & 0.859 & 100 & 75.69 \\
\hline
\end{tabular}


Beginning with the lowest end of the sanitation ladder, open defecation records the percentage of the population in a country-year engaging in the practice. Open defecation is defined as "disposal of human feces in fields, forests, bushes, open bodies of water, beaches and other open spaces with solid waste" and is generally not considered to meet the minimum standards of the human right to sanitation. These data are available from 2000 through 2017 and are missing in $9.43 \%$ of observations. Higher up the ladder, basic sanitation records the percentage of population in a country year with access to "improved facilities which are not shared with other households." Prior to the establishment of the SDGs, the MDG's utilized a similar measure, referred to as improved sanitation. Next, safe sanitation, identified as the target in SDG number six, refers to "the use of improved facilities which are not shared with other households and where excreta are safely disposed in situ or transported and treated off-site." This is again measured as the percentage of a country-year population with access. Finally, basic handwashing records the percentage of a country-year population that has "availability of handwashing facility on premises with soap and water" [16].

Figure 1 below plots the average rates of each of these measures from 2000-2017 globally (solid line) along with the rate of missing data in each year (dotted line). Examining Figure 1, we can see that the average rate of access to basic sanitation has hovered between $65 \%$ and $75 \%$ in this timeframe. Missing data in this period ranges from about $7 \%$ to $14 \%$. Moving to safe sanitation, the figures are considerably worse. Between 2000 and 2017, average rates of access were between $59 \%$ and $68 \%$ and at no time were less than $59 \%$ of the data missing. With more observations missing than reported, it is difficult to determine the validity of the averages reported. Next, examining basic handwashing, data are similarly sparse. Averages in the 2000 to 2017 period are between $25 \%$ and $50 \%$ access. The proportion of missing data is between $54 \%$ and $95 \%$. This again leads to questions concerning the veracity of the figures reported concerning access to basic handwashing facilities. Finally, examining open defecation, the figures are considerably more widely available. Average yearly rates are between $7 \%$ and $14 \%$ and data were missing at a rate between $8 \%$ and $13 \%$.

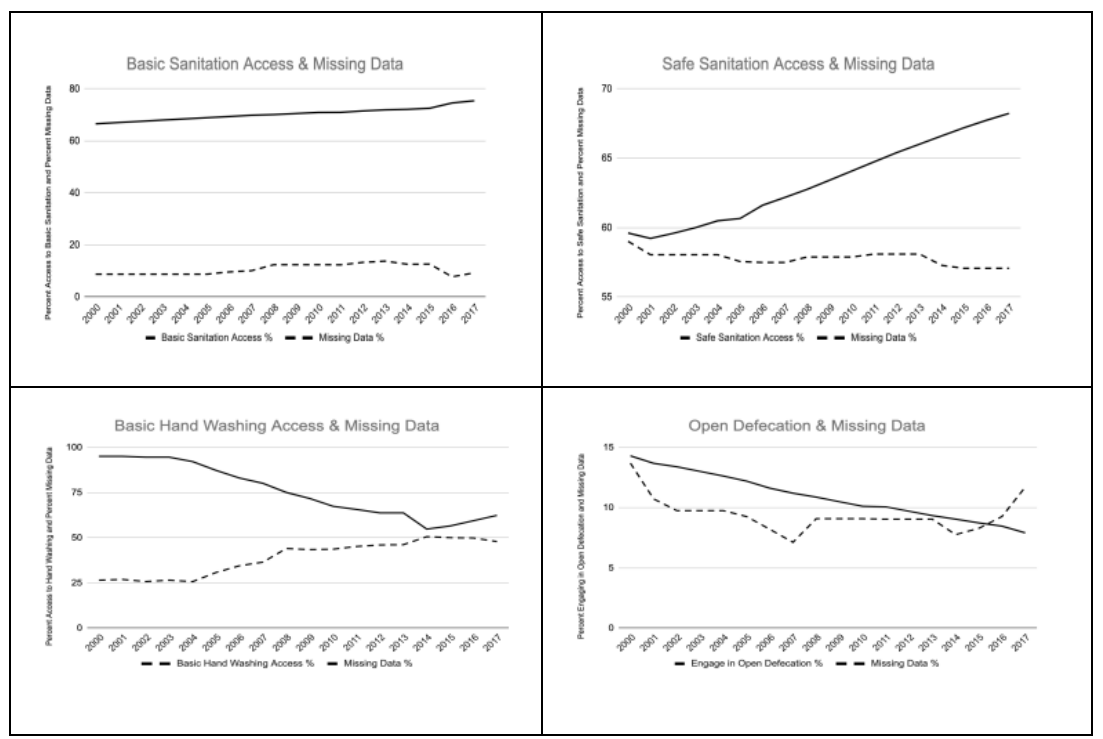

Figure 1. Sanitation Averages and Missing Data.

Beyond examining the proportion of missing observations yearly, however, it is important to determine the extent to which the missing data may be biased with respect to important characteristics related to sanitation access. For instance, prior literature has shown an association between sanitation access and income level [10,19-22]. Further, we know that certain regions of the world suffer from worse rates of sanitation than others. For 
these reasons, it is beneficial to examine whether the missing data are distributed evenly among the sample or if the missing data occur primarily in one geographic or development group. Figure 2 below examines missing data regionally, reporting the percent of missing data for four sanitation measures according to UN regional classifications.

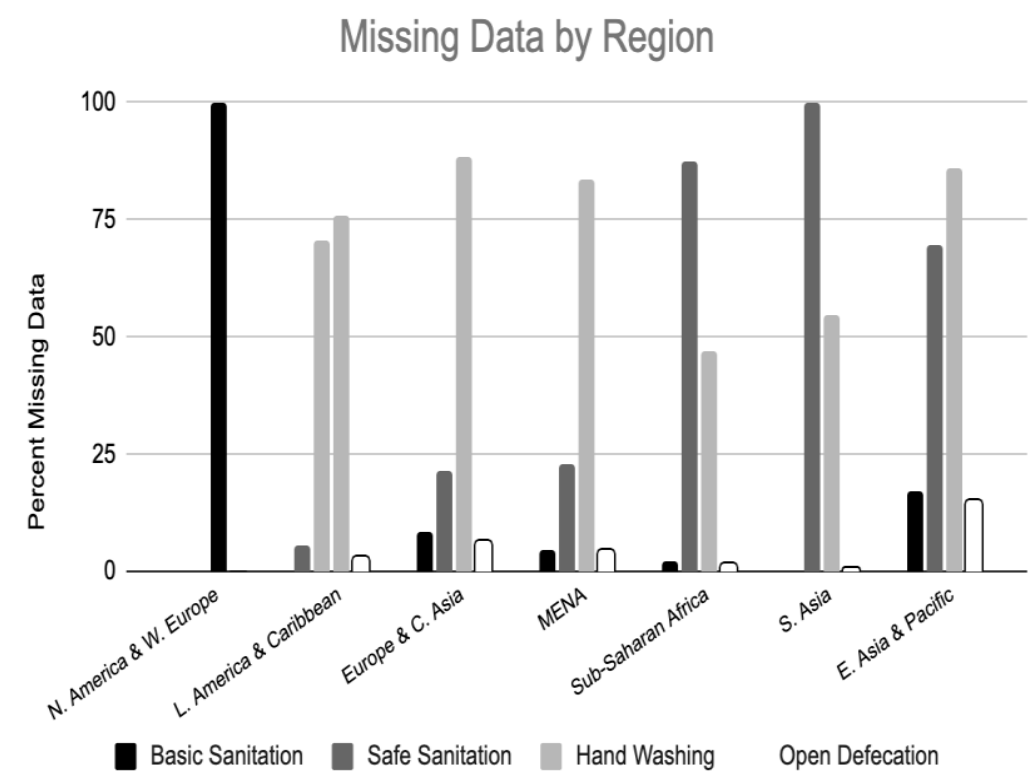

Figure 2. Missing Data Regionally.

Figure 2 reports the proportion of missing data concerning basic sanitation, safe sanitation, basic handwashing, and open defecation by seven global regions. Basic sanitation and open defecation measures are the most widely among the four measures. However, the region with the highest proportions of missing data on these measures is East Asia and the Pacific, reporting $69 \%$ access to basic sanitation and $11 \%$ average open defecation rates from 2000 to 2017. This means that the greatest proportion of missing data on these measures occurs in a region suffering the third-worst sanitation and open defecation rates globally. Turning to the measure of safe sanitation, all regions report very high degrees of missing data. However, the highest rates of missing data occur in Latin America and Sub-Saharan Africa, the two regions reporting the worst rates of safe sanitation access. Finally, basic handwashing is the least-available measure among the four and this is reflected in Figure 2. Here, Sub-Saharan Africa has the highest rate of available data, as one might expect for the region with the worst rates of access.

Figure 3 again reports the rate of missing data on the four sanitation measures, this time examining the rate of missing observations according to World Bank Development category. Interestingly, there appears to be less relevant bias in missing basic sanitation data in this category, with the highest rate of missing observations occurring in the wealthiest group of states. In contrast, examining safe sanitation, this is not the case. It appears that missing safe sanitation data is directly correlated with income, with the highest degrees of missing data occurring in the least-developed group of states and the lowest rate of missing data in the group of states at the highest level of development. In short, any assessment utilizing these data will draw conclusions that are primarily based on wealthy states. Next, handwashing shows an opposite relationship with most data missing from wealthy states. It is important to keep in mind here that data for both the safe sanitation measure and the basic handwashing measure are more absent than available; and having a lower degree of missing data does not equate to having adequate data. Finally, open defecation data are similar to the handwashing data with the highest proportion of missing data occurring in the wealthiest group of states. 


\section{Missing Data by Income Group}

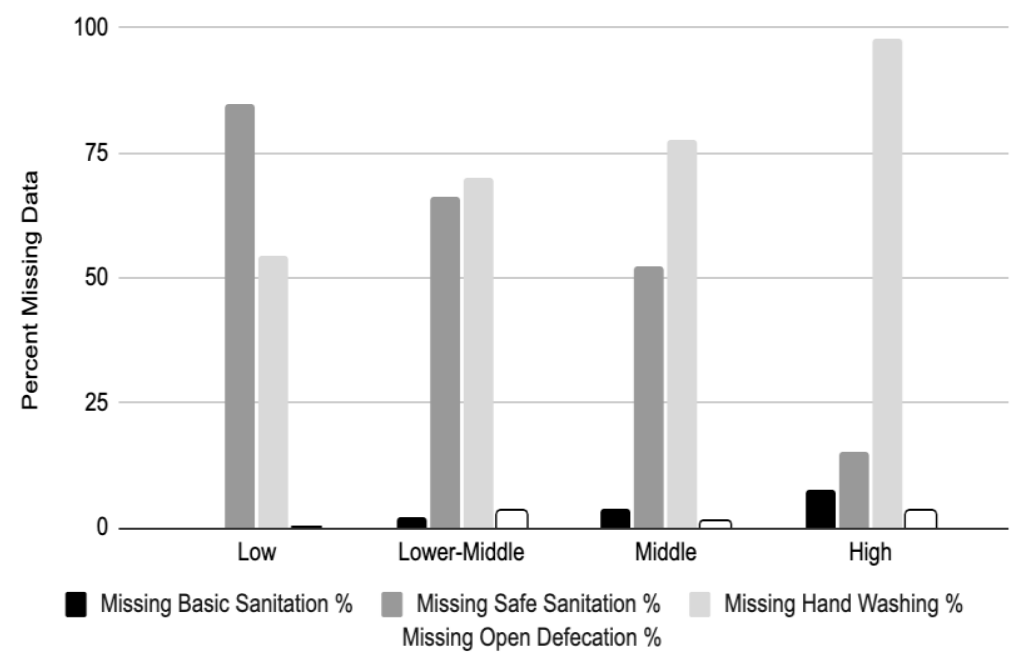

Figure 3. Missing Data by Development.

Examining the development-wealth nexus further, we investigate whether the connection between sanitation access and data quality is more systemic. Figure 4 reports the percentage of missing data for safe sanitation (the benchmark utilized in SDG goal six) according to rates of basic sanitation access, organized by quartiles. The results suggested by this figure are striking: There appears to be a direct correlation between sanitation context in a state and degree of missing data. For instance, states with the lowest $25 \%$ average of basic sanitation access report the highest percentage of missing data on the safely managed sanitation measure $(86.4 \%)$. Alternatively, states in the highest quartile of basic sanitation access report the lowest rates of missing data on safely managed sanitation $(11.93 \%)$. This suggests that beyond the general issue of missing data, data are missing in a manner that imparts significant bias on any assessment.

Missing Safe Sanitation and According to Basic Sanitation Averages

100

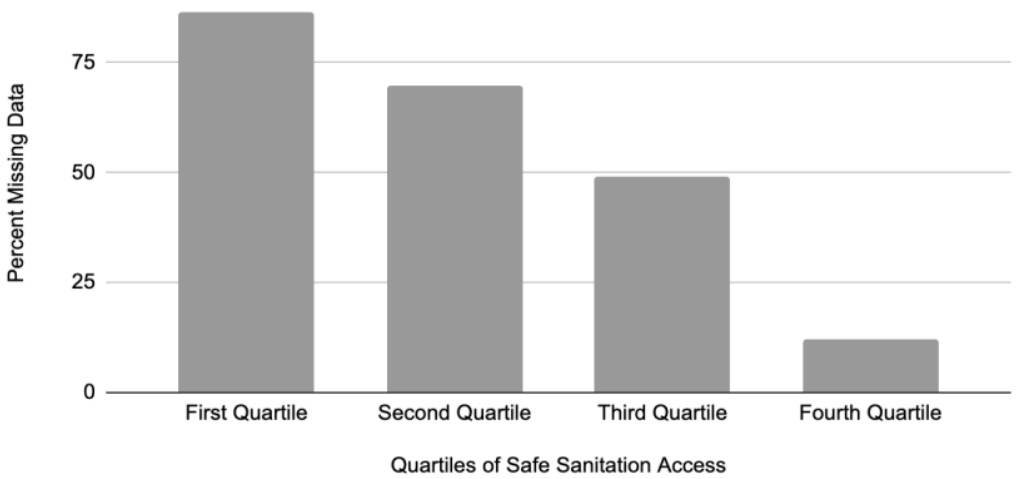

Figure 4. Missing Safe Sanitation Access according to Basic Sanitation Averages.

Combining the assessment of data quality and availability we are left with the following findings. First, data concerning the SDG-identified target measure of safely managed sanitation are more likely to be missing than available. Second, the missing data on this measure appear to be missing in the regions and states most in need of improvement. Third, basic sanitation and open defecation measures are considerably more widely available. However, given that safe sanitation was specifically targeted as the metric utilized in SDG number six, and the available measures focus on basic sanitation proximity and the occurrence of open defecation, there is little to be gleaned in terms of progress toward 
measuring achieving SDG targets or higher levels of the right to sanitation. While we may be able to gauge improvements in the prevalence of open defecation in a state, this tells us nothing about the proportion of individuals with access to safely managed sanitation.

The question posed at the outset of this research was twofold, asking what effects rights might have on sanitation progress and second, whether the available data could answer this question. The following section describes our empirical approach using available sanitation data.

\section{Results}

Data and Methods

Given the data availability issues described above, and the likely introduction of bias into any assessment utilizing available data on higher order measures of sanitation, we opt to test the effects of rights on the two widely available measures of sanitation access: open defecation and basic sanitation. Table 2 provides descriptive statistics on all measures utilized in the analysis. The data for the dependent variables are panel, available from 2000-2017 on a global sample of states, and since the dependent variables are continuous, we utilize ordinary least squares (OLS) regression. We cluster standard errors by country to avoid heteroskedasticity. The data concerning sanitation utilize the two most widely available measures, discussed above, basic sanitation access and open defecation. Each table below uses one of these measures as the primary dependent variable with basic sanitation utilized in Table 3 and open defecation utilized in Table 4.

Table 2. Descriptive Statistics.

\begin{tabular}{cccccc}
\hline Variable & Obs. & Mean & Std. Dev. & Min & Max \\
\hline Basic Sanitation & 3325 & 70.37 & 29.91 & 6.6 & 100 \\
Open Defecation & 3371 & 10.92 & 17.71 & 0 & 84.59 \\
Sanitation Right & 3642 & 0.115 & 0.319 & 0 & 1 \\
Water Right & 3752 & 0.194 & 0.396 & 0 & 1 \\
Health Right & 3474 & 1.083 & 0.842 & 0 & 2 \\
GDP pc (ln) & 3003 & 8.244 & 1.602 & 4.664 & 12.174 \\
Ethnolinguistic Fractionalization & 1642 & 0.408 & 0.279 & 0.001 & 0.925 \\
Population (ln) & 3450 & 15.479 & 2.212 & 9.148 & 21.05 \\
Area (ln) & 3095 & 2.54 & 0.19 & 1.515 & 2.87 \\
EPI & 1942 & 53.296 & 11.894 & 15 & 91 \\
\hline
\end{tabular}

Table 3. Rights \& Basic Sanitation Access, 2000-2017.

\begin{tabular}{cccc}
\hline & (1) Sanitation & (2) Water & (3) Health \\
\hline Rights & -5.00762 & -4.81011 & 0.95469 \\
& $(5.82758)$ & $(4.83942)$ & $(2.38882)$ \\
\hline GDP per capita & $2.74563^{* *}$ & $2.74770^{* *}$ & $2.76599^{* *}$ \\
$(\ln )$ & $(0.48338)$ & $(0.48287)$ & $(0.48090)$ \\
\hline Fractionalization & $-45.86664^{* *}$ & $-46.24426^{* *}$ & $-45.82849^{* *}$ \\
& $(8.56423)$ & $(8.63061)$ & $(8.57493)$ \\
\hline Population $(\ln )$ & $6.66139^{* *}$ & $6.62304^{* *}$ & $6.51812^{* *}$ \\
& $(2.48829)$ & $(2.48337)$ & $(2.43654)$ \\
\hline Area $(\ln )$ & $-54.18238^{*}$ & $-53.30422^{*}$ & $-54.26008^{*}$ \\
& $(26.18145)$ & $(26.34412)$ & $(26.35693)$ \\
\hline EPI & $0.29475^{* *}$ & $0.29466^{* *}$ & $0.29488^{* *}$ \\
& $(0.10673)$ & $(0.10680)$ & $(0.10634)$ \\
\hline Constant & $85.03706^{+}$ & $83.85600^{+}$ & $85.71024^{+}$ \\
& $(47.86404)$ & $(47.98090)$ & $(48.32989)$ \\
\hline Observations & 1334 & 1334 & 1334 \\
\hline
\end{tabular}

Standard errors in parentheses. $+p<0.1^{*} p<0.05^{* *} p<0.01$. 
Table 4. Rights \& Open Defecation, 1990-2017.

\begin{tabular}{cccc}
\hline & (1) Sanitation & (2) Water & (3) Health \\
\hline Rights & 3.65621 & 3.65090 & -1.84974 \\
& $(4.18866)$ & $(3.65458)$ & $(1.52376)$ \\
\hline GDP per capita & $-1.74369^{* *}$ & $-1.74785^{* *}$ & $-1.77068^{* *}$ \\
$(\ln )$ & $(0.46369)$ & $(0.46064)$ & $(0.46317)$ \\
\hline Fractionalization & $18.30207^{* *}$ & $18.59557^{* *}$ & $18.31598^{* *}$ \\
& $(5.37350)$ & $(5.39858)$ & $(5.40123)$ \\
\hline Population $(\ln )$ & $-6.41315^{* *}$ & $-6.35129^{* *}$ & $-6.24453^{* *}$ \\
& $(2.05595)$ & $(2.05384)$ & $(2.00366)$ \\
\hline Area $(\ln )$ & $50.90849^{* *}$ & $49.98533^{*}$ & $50.99265^{* *}$ \\
& $(19.66807)$ & $(19.61335)$ & $(19.60441)$ \\
\hline EPI & -0.14825 & -0.14806 & -0.14917 \\
& $(0.09756)$ & $(0.09731)$ & $(0.09672)$ \\
\hline Constant & -1.67740 & -0.65768 & -1.70055 \\
& $(31.22260)$ & $(31.18719)$ & $(31.69330)$ \\
\hline Observations & 1323 & 1323 & 1323 \\
\hline Standard errors in parentheses. $+p<0.1^{*} p<0.05^{* *} p<0.01$. & &
\end{tabular}

In the tests in Tables 3 and 4, we employ three different measures of rights related to sanitation: Water, Sanitation, and Health. First, we utilize a dichotomous measure of whether a state includes a right to water in their national constitution, labeled, Water, where states with a right are coded as 1 and states without a right are coded as 0 . This measure was derived from author coding of all state constitutions recorded in the Comparative Constitutions Project. Like the prior measure, we include a dichotomous measure of whether a state has a right to sanitation included in their constitution, labeled Sanitation. This measure was also derived from author coding of all state constitutions recorded in the Comparative Constitutions Project and takes the value of 1 in states that include the right and 0 in states where no such right is included [63]. Finally, given that sanitation is inextricably linked to health, we include a dichotomous measure of a right to health in national constitutions, labeled Health [38]. This measure is coded as 1 where the right exists and 0 where it is absent. These data were derived from the Toronto Initiative on Economic and Social Rights [64].

Finally, all models in Tables 3 and 4 utilize the same five control variables, theoretically linked to sanitation access. These include the natural log of GDP per capita, ethnolinguistic fractionalization, the natural log of population, the natural log of land area, and a measure of environmental performance. First, development has been directly linked with sanitation, with the poorest countries in the world generally suffering from the worst rates of sanitation access. These data are derived from the World Bank and are reported in 2010 Constant US dollars. Next, ethnolinguistic fractionalization is operationalized as a HerfindahlHirschman index with larger numbers denoting a more homogenous population. Studies have shown that more homogenous populations are associated with greater rates of public goods provision as coordination costs are thought to be lower [65]. These data are derived from the Ethnic Power Relations database [66]. Next, we examine total population and total land area, utilizing the natural logs, as both larger populations and those spread out over larger areas should theoretically present more difficulties in the provision of sanitation access. These data are derived from the World Bank. Finally, examining environmental factors, we utilize the Environmental Performance Index (EPI) from Yale University. The measure is comprised of several indicators of environmental health and ecosystem vitality with higher scores indicating better environmental performance [67].

Tables 3 and 4 present the results of eight models examining the effects of rights on access to sanitation. Table 3 examines basic sanitation as the dependent variable and Table 4 examines improved sanitation. Each of the models, 1-3, in Tables 3 and 4 then 
examine a different independent variable conceptualizing rights related to sanitation. The independent variable examined in each model is denoted next to the model number in the top row.

Table 3 displays three different operationalizations of rights related to sanitation and their effect on basic sanitation access from 2000-2017. Models 1-3 examine separately rights in national constitutions with model 1 utilizing the right to sanitation, model 2 the right to water, and model 3 the right to health. In all three models the rights terms fail to reach statistical significance, suggesting little correlation between having a right related to sanitation enshrined in a constitution and increased basic sanitation access.

Next, Table 4 examines the same three independent variables with an alternative dependent variable, open defecation. Similar to the results in Table 3, the three rights variables examining rights to sanitation, water, and health fail to achieve statistical significance. These results again suggest the lack of a correlation between rights and open defecation.

Beyond the rights terms, however, results elsewhere in the two tables are fairly robust. GDP per capita, population, and EPI have a positive and significant correlation with basic sanitation and a negative, and sometimes significant, correlation with rates of open defecation. Alternatively, fractionalization and land area are consistently negatively correlated with basic sanitation and consistently positively correlated with open defecation. While data concerning safe sanitation are missing to a degree that would introduce a great deal of bias into the model, measures of both basic sanitation and open defecation produce significant results. Further, the lack of any meaningful results related to rights in these models suggests that rights alone may have little impact on even basic levels of sanitation.

\section{Conclusions}

This article contributes to the literature by providing a systematic assessment of data available to study sanitation access. In so doing, we first point out issues with data availability data and the implications for sanitation research. Second, by utilizing the (inadequate) available data in estimating the impact of rights recognition on sanitation access, we point out that even the lowest levels of sanitation access are not improved by rights recognition.

This article set out several findings from our assessment of the literature, data, and empirical tests. We have identified some cases studies that indicate how the legal recognition can generate material, political and symbolic impacts. However, it is challenging to measure this at a macro level. First, available data reporting SDG sanitation targets are missing in more observations than are available. Second, the availability of these data suffers from serious degrees of reporting bias related to development, geography, and current sanitation context. Third, the measures suffering from the least bias and available with the greatest frequency tell us little about current progress toward SDG sanitation targets, or sanitation context more generally.

Our results failed to illustrate that rights can improve access to sanitation in a meaningful way. In contrast, our quantitative analysis suggests that other factors are correlated with improved access to sanitation. Taken together, our results suggest that rights are not likely, on their own, to affect sanitation outcomes. Instead, wealth, geography, and aid appear more highly correlated with sanitation outcomes. Moreover, in previous research on the constitutionalisation of the right to water, we have illustrated the conditional effects of rights [49] as we found a positive impact of the recognition of the human right to water for higher levels of democratic governance. However, we have been unable to replicate these findings for the right to sanitation due to the lack of available data.

Beyond our study of the effects of rights, however, the available data do not leave researchers with many options for accurately assessing progress toward SDG sanitation targets, or other factors related to sanitation access including aspects related to the sustainability of sanitation programs. Instead, this research illustrates that until data are more widely available, relevant to development targets, and missing in less biased fashions, it will be difficult to understand which factors either help or hinder progress on sanitation. 
Consequently, it is necessary to engage in an effort to collect relevant, quality data from the regions of the world suffering from the lowest degrees of safe sanitation access. This is, no doubt, both a priority of the JMP and a substantial challenge. Until such time, however, researchers should use caution in both relying on the available data and any findings derived from them. We also encourage future studies to include discussions of sustainable access to sanitation to better align research and policy with the UN's SDGs. While this is very important, the topic is beyond the purview of this current article.

Author Contributions: Conceptualization: R.S., B.M.W. and M.L. Methodology: R.S. Software: R.S. Validation: R.S. Analysis: R.S. Investigation: R.S., B.M.W. and M.L. Resources: B.M.W. and M.L. Data Curation: R.S. Writing-original draft preparation: R.S., B.M.W. and M.L. Writing-review and editing: R.S., B.M.W. and M.L. Visualization: R.S. Funding acquisition: B.M.W. All authors have read and agreed to the published version of the manuscript.

Funding: Research funded by the Norwegian Research Council. "Elevating Water Rights to Human Rights: Has it strengthened marginalized peoples' claim for water? (Forskerprosjekt-FRIHUMSAM project number 263096). P.I. Bruce M. Wilson and the University of Central Florida Preeminent Postdoctoral Program (P3) grant number 0000007509; P.I. Bruce M. Wilson.

Data Availability Statement: Data utilized in this study can be found at the links provided in the reference list.

Acknowledgments: The authors would like to thank Kerstin Hamann for insightful, helpful suggestions on an earlier version of this manuscript.

Conflicts of Interest: The authors declare no conflict of interest.

\section{References}

1. UN. General Assembly. The Human Right to Water and Sanitation. U.N. Doc A/64/L.63/Rev.1, Para. 1. Available online: https: / / undocs.org/A/64/L.63/Rev.1 (accessed on 19 March 2021).

2. United Nations Conference on Water, Mar del Plata Action Plan (1977), Mar Del Plata Action Plan Resolution, Preamble. Available online: https:/ / www.internationalwaterlaw.org/bibliography/UN/Mar_del_Plata_Report.pdf (accessed on 19 March 2021).

3. United Nations. Division for the Advancement of Women. In Convention on the Elimination of All Forms of Discrimination against Women; United Nations: New York, NY, USA, 1981.

4. United Nations, Committee on Economic, Social and Cultural Rights. General Comment No. 15, The Human Right to Water and Sanitation, U.N. Doc. E/C.12/2002/11. Available online: https://www.undocs.org/e/c.12/2002/11 (accessed on 19 March 2021).

5. Langford, M.; Bartram, J.; Roaf, V. The Human Right to Sanitation. In The Human Right to Water: Theory, Practice and Prospects; Langford, M., Russell, A., Eds.; Cambridge University Press: Cambridge, UK, 2017; pp. 345-395.

6. Winkler, I. The Human Right to Sanitation. Univ. Pa. J. Int. Law 2016, 37, 1331.

7. Patunru, A. Access to Safe Drinking Water and sanitation in Indonesia. Asia Pac. Policy Stud. 2015, 2, 234-244. [CrossRef]

8. Cumming, O.; Elliot, M.; Overbo, A.; Bartram, J. Does global progress on sanitation really lag behind water? An Analysis of global progress in community- and household-level access to safe water and sanitation. PLoS ONE 2014, 9, e114699. [CrossRef] [PubMed]

9. Bartram, J. Improving on Haves and Have-Nots. Nature 2008, 452, 283-284. [CrossRef] [PubMed]

10. Armah, F.; Ekumah, B.; Yawson, D.; Odoi, J.; Afitiri, A.; Nyieku, F. Access to improved water and sanitation in sub-Saharan Africa in a quarter century. Heliyon 2018, 4, e00931. [CrossRef] [PubMed]

11. Millennium Development Goals. United Nations Millennium Goals. Available online: https://www.un.org/millenniumgoals/ environ.shtml (accessed on 26 March 2021).

12. UNICEF and World Health Organization. Progress on Sanitation and Drinking Water: 2015 Update and MDG Assessment. 2015. Available online: https:/ / www.who.int/water_sanitation_health/publications/jmp-2015-update/en/ (accessed on 19 March 2021).

13. The Millennium Development Goals Report. United Nations Millennium Development Goals. 2015. Available online: https: //www.un.org/millenniumgoals/2015_MDG_Report/pdf/MDG\%202015\%20rev\%20(July\%201).pdf (accessed on 21 March 2021).

14. Goal Number Six Identifies Eight Targets for 2030, Two of Which Are Directly Related to Safely Managed Sanitation Access. These Targets Include Achieving Access to: (1) "Adequate and Equitable Sanitation and Hygiene for all and an End to Open Defecation, Paying Special Attention to the Needs of Women and Girls and Those in Vulnerable Situations"; and (2) "Halving the Proportion of Untreated Wastewater and Substantially Increasing Recycling and Safe Reuse Globally". "Water and Sanitation". United Nations Sustainable Development. Available online: https://www.un.org/sustainabledevelopment/water-and-sanitation/ (accessed on 22 March 2021). 
15. United Nations, Department of Economic and Social Affairs, Sustainable Development. Progress. Available online: https: / / sdgs.un.org/goals/goal6 (accessed on 19 March 2021).

16. World Health Organization. Definitions of Indicators. Available online: https://www.who.int/water_sanitation_health/ monitoring/jmp04_2.pdf (accessed on 22 March 2021).

17. SDG Tracker: Clean Water and Sanitation. Sustainable Development Goal 6. Available online: https://sdg-tracker.org/waterand-sanitation (accessed on 21 March 2021).

18. UN Statistics. Sustainable Development Goals Report. 2020. Available online: https://unstats.un.org/sdgs/report/2020/goal-06 / (accessed on 21 March 2021).

19. Abubakar, I. Access to sanitation facilities among Nigerian households: Determinants and sustainability implications. Sustainability 2017, 9, 547. [CrossRef]

20. Adams, E.; Boateng, G.; Amoyaw, J. Socioeconomic and Demographic Predictors of Potable Water and Sanitation Access in Ghana. Soc. Indic. Res. 2016, 126, 673-687. [CrossRef]

21. Rheingans, R.; Anderson, J.; Luyendijk, R.; Cumming, O. Measuring Disparities in Sanitation Access: Does the measure matter? Trop. Med. Int. Health 2014, 1, 2-13. [CrossRef] [PubMed]

22. Andersson, P.; Kumar, N.; Sokou, E.; Roman, O.Z.; Wang, Y.; Savić, P. Inequality of Opportunity in Asia and the Pacific: Water and Sanitation. Social Development Policy Papers \#2018-5. Available online: https://www.unescap.org/sites/default/d8files/ knowledge-products/Water_Sanitation_report_20181122.pdf (accessed on 11 June 2021).

23. Van Minh, H.; Viet Hung, N. Economic Aspects of Sanitation in Developing Countries. Environ. Health Insights 2011, 5, 63-70. [CrossRef] [PubMed]

24. Ndikumana, L.; Pickbourn, L. The Impact of foreign aid allocation on access to social services in sub-Saharan Africa: The Case of water and sanitation. World Dev. 2017, 90, 104-114. [CrossRef]

25. Lawrence, J.; Yeboah-Antwi, K.; Biemba, G.; Ram, P.; Osbert, N.; Sabin, L.; Hamer, D. Beliefs, Behaviors, and Perceptions of Community-Led Total Sanitation and Their Relation to Improved Sanitation in Rural Zambia. Am. J. Trop. Med. Hyg. 2016, 94, 553-562. [CrossRef] [PubMed]

26. WaterAid. Available online: https://www.wateraid.org/us (accessed on 14 June 2021).

27. Centre on Housing Rights and Evictions (COHRE). Available online: https://www.cohre.org/ (accessed on 14 June 2021).

28. COHRE; UN-HABITAT; WaterAid; SDC. Sanitation: A Human Rights Imperative; COHRE: Geneva, Switzerland, 2008 ; p. 5.

29. International Conference on Water and the Environment: Development Issues for the 21st Century, 'Dublin Statement on Water and Sustainable Development', U.N. Doc. A/Conf.151/PC/112 (1992). Emphasis Added. It Was Not a Formal Govern-Ment Declaration, but the Statement Was Endorsed by International Experts from a Hundred Countries. It Is Also a Formal U.N. Document. Available online: https:/ / www.gdrc.org/uem/water/dublin-statement.html (accessed on 14 June 2021).

30. UN-Habitat. The Habitat Agenda Goals and Principles, Commitments and the Global Plan of Action; UN-Habitat: Nairobi, Kenya; Istanbul, Turkey, 1996; para. 11.

31. In Proceedings of the 17th Plenary Meeting of the World Summit on Sustainable Development, Johannesburg, South Africa, 4 September 2002. Available online: https://www.un.org/esa/sustdev/documents/WSSD_POI_PD/English/POI_PD.htm (accessed on 14 June 2021).

32. General Comment No. 15 (2002), Para. 3 States, "Article 11, Paragraph 1, of the Covenant Specifies a Number of Rights Ema-Nating from, and Indispensable For, the Realization of the Right to an Adequate Standard of Living 'Including Adequate Food, Clothing and Housing.' the Use of the Word 'Including' Indicates That This Catalogue of Rights Was Not Intended to Be Exhaus-Tive. The Right to Water Clearly Falls within the Category of Guarantees Essential For Securing an Adequate Standard of Living, Particularly since It Is One of the Most Fundamental Conditions for Survival. Moreover, the Committee Has Previously Rec-Ognized That Water Is a Human Right Contained in Article 11, Paragraph 1, (See General Comment No. 6 (1995)). The Right to Water Is Also Inextricably Related to the Right to the Highest Attainable Standard of Health (Art. 12, Para. 1) And the Rights to Adequate Housing and Adequate Food (Art. 11, Para. 1). The Right Should Also Be Seen in Conjunction with Other Rights en-Shrined in the International Bill of Human Rights, Foremost Amongst Them the Right to Life and Human Dignity." Para. 4 Continues, "the Right to Water Has Been Recognized in a Wide Range of International Documents, Including Treaties, Declara-Tions and Other Standards". Available online: https://www.unhcr.org/en-us/publications/operations /49d095742/ committee-economic-social-cultural-rights-general-comment-15-2002-right.html (accessed on 14 June 2021).

33. The United Kingdom Delegation Abstained in the Vote Because They Claimed there Was Insufficient Legal Basis for Recognizing Water or Sanitation as Freestanding Human Rights and that there Was No Evidence that the Rights Existed in Customary law. General Assembly Adopts Resolution Recognizing Access to Clean Water, Sanitation. UN Information Release. 28 July 2010. Available online: http:/ / www.un.org/News/Press/docs/2010/ga10967.doc.htm (accessed on 11 June 2021).

34. "The Committee Reaffirms that, since Sanitation is Fundamental for Human Survival and for Leading a Life in Dignity, the Right to Sanitation is an Essential Component of the Right to an Adequate Standard of Living, Enshrined in Article 11 of the International Covenant on Economic, Social and Cultural Rights. The Right to Sanitation is also Integrally Related, among other Covenant Rights, to the Right to Health, as Laid down in Article 12 paragraphs 1 and 2 (a), (b) and (c), the Right to Housing, in Article 11, as Well as the Right to Water, Which the Committee Recognized in Its General Comment No. 15."UN Committee on Economic, Social and Cultural Rights. Statement on the Right to Sanitation. (Forty-Fifth Session, 2010), UN Doc. E/C.12/2010/ 1, Para. 7. Available online: https:/ / undocs.org/en/A/HRC/15/31 (accessed on 14 June 2021). 
35. UN Human Rights Council. Report of the Independent Expert on the Issue of Human Rights Obligations Related to Access to Safe Drinking Water and Sanitation, Catarina de Albuquerque. (Fifteenth Session, 2010) UN Doc. A/HRC/15/31, Paras. 13-54. Available online: https: / / undocs.org/en/A/HRC/15/31 (accessed on 14 June 2021).

36. States with constitutional rights to water include the "Democratic Republic of the Congo, Ecuador, Maldives, Mexico, Nicaragua, Solomon Islands, South Africa, Uganda, United States of America (at state level), and Uruguay ... " Heller, L. "Statement by the Special Rapporteur on the human rights to safe drinking water and sanitation". 28 July 2020. Available online: https: //www.ohchr.org/EN/NewsEvents/Pages/DisplayNews.aspx?NewsID=26116\&LangID=E (accessed on 14 June 2021).

37. Committee on Economic, Social and Cultural Rights. General Comment 4, The Right to Adequate Housing. (Sixth Session, 1991), U.N. Doc. E/1992/23, Annex III at 114 (1991), Para. 8(b). Available online: https://www.refworld.org/pdfid/47a7079a1.pdf (accessed on 14 June 2021).

38. Committee on Economic, Social and Cultural Rights. General Comment 14, the Right to the Highest Attainable Standard of Health. (Twenty-Second Session, 2000), U.N. Doc. E/C.12/2000/4 (2000), Para 4. Available online: https://www.refworld.org/pdfid/45 38838d0.pdf (accessed on 14 June 2021).

39. Wilson, E.F. Human Rights-Based Approach to Development: The Right to Water. Neth. Q. Hum. Rights 2005, $23,213-241$. [CrossRef]

40. Banik, D. Support for Human Rights-Based Development: Reflections on the Malawian Experience. Int. J. Hum. Rights 2010, 14, 32-48. [CrossRef]

41. Joel Bolnick, a Co-founder of Slum Dwellers International, for Example, Rejects a Rights-Based Approaches. He Believes That "Public Declarations Have a Habit of Compromising Our Capacity to Negotiate with and on Behalf of Organised Shack Dwellers". J. Bolnick, 'Slum-Friendly Approach: Sdi Letter to the Witness in Response to Article by Ndivhuwo WA Ha Mabaya' (2009). Available online: https:/ / abahlali.org/node/4859/ (accessed on 14 June 2009).

42. Ramphele, M. Cited in P. Green, '100 days, 11 issues'. Mail E Guardian, 17 August 2009.

43. Dembour, M.-B. What Are Human Rights? Four Schools of Thought. In Human Rights Quarterly; The Johns Hopkins University Press: Baltimore, MD, USA, 2010; Volume 32, pp. 1-20.

44. Neocosmos, N. Civil Society, Citizenship and the Politics of the (Im)possible: Rethinking Militancy in Africa Today. Interface 2009, 1,263-334.

45. Langford, M. Critiques of Human Rights. Annu. Rev. Law Soc. Sci. 2018, 14, 69-89. [CrossRef]

46. Sikkink, K. Evidence for Hope: Making Human Rights Work in the 21st Century; Princeton University Press: Princeton, NJ, USA, 2017.

47. Langford, M.; Rodriguez, C.; Ross, J. (Eds.) Social Rights Judgments and the Politics of Compliance: Making It Stick; Cambridge University Press: Cambridge, UK, 2017.

48. Schiel, R.; Langford, M.; Wilson, B.M. Does it matter? Constitutionalisation, democratic governance, and the human right to water. Water 2020, 12, 350. [CrossRef]

49. Crawford, S.; Brocklesby, M.A. Assessing the Impact of a Right to Sanitation on Improving Levels of Access and Quality of Services: Summary; DFID Draft Working Paper; OECD: Paris, France, 2011.

50. WASHWatch. South Asia/Nepal: Summary. Available online: http://www.washwatch.org/southern-asia/nepal (accessed on 11 June 2017).

51. Langford, M. The Right to Water and Sanitation in Development Cooperation: The State of Play and the European Union; Briefing Paper for the European Parliament; European Parliament: Brussels, Belgium, 2012.

52. Rampal and Ors v. State of Rajasthan and Ors. AIR1981Raj121 (4 September 1980). Available online: https://www.legitquest.com/ case/rampal-sharma-and-others-v-state-of-rajasthan/1c0eb0 (accessed on 14 June 2021).

53. Human Rights Case No. 9-K/1992; Supreme Court of Pakistan, Unreported Judgment. Available online: https://www. supremecourt.gov.pk/cause-list-search/ (accessed on 14 June 2021).

54. Karachi Administration Employees Co-operative Housing Society and the Karachi Water and Sewerage Board (KWSB). Available online: http:/ / www.kwsb.gos.pk/ (accessed on 14 June 2021).

55. Legal Resources for the Right to Water and Sanitation: International and National Standards, 2nd ed.; COHRE: Geneva, Switzerland, 2008.

56. $\quad$ Robins, S. Toilets that became political dynamite. Cape Times, 27 June 2011.

57. Beja and Others $v$ Premier of the Western Cape and Others. [2011] 3 All SA 401 (WCC)) [2011] ZAWCHC 97, 21332/10 (29 April 2011). Available online: http: / www.saflii.org/za/cases /ZAWCHC/2011/97.html (accessed on 14 June 2021).

58. Kiewietz, J.; Jooste, B. Residents elated to have enclosed toilets. IOL News, 29 August 2011.

59. Justice Erasmus also Criticised the Two Parties' Politicisation of the Toilet Issue at the Expense of the Community and Directly Questioned Youth League's Integrity. The Judgment Stated: "What has Become Evident Is that the [ANC Youth League] had a Core Function of Promoting the Interests of the City Contractor ... Not only Was the [ANC Youth League] in the Pocket of the Contractor but His Role Undermined the Principle of Community Participation". Beja v Premier of the Western Cape. (n. 228 above), Para. 104. Available online: http:/ / www.saflii.org/za/cases/ZAWCHC/2011/97.html (accessed on 14 June 2021).

60. Dugard, J. Basic Services in Urban South Africa: Rights, Reality and Resistance. In Symbols or Substance? The Role and Impact of Socio-Economic Rights Strategies in South Africa; Langford, M., Cousins, B., Dugard, J., Madlingozi, T., Eds.; Cambridge University Press: Cambridge, UK, 2013. 
61. Liebenberg, S. Nokotyana \& Ors. v. Ekurhuleni Municipality 2010 (4) BCLR 312 (CC). The Court did not address the existence of a constitutional right to sanitation, rather it focused on the legislation in its decision. In Socio-Economic Rights: Adjudication under a Transformative Constitution; Juta Academic: Cape Town, Western Cape, South Africa, 2010; pp. 455-456.

62. Joint Monitoring Programme: WHO \& UNICEF. Sanitation. Available online: washdata.org (accessed on 22 March 2021).

63. Elkins, Z.; Ginsburg, T.; Melton, J. Comparative Constitutions Project: Characteristics of National Constitutions. 2005 [2021]. Characteristics of National Constitutions [v.2.0]. Available online: comparativeconstitutionsproject.org (accessed on 9 June 2021).

64. Jung, C.; Hirschl, R.; Rosevear, E. Economic and Social Rights in National Constitutions. Am. J. Comp. Law 2014, 62, 1043-1093. [CrossRef]

65. Habyarimana, J.; Humphreys, M.; Posner, D.; Weinstein, J. Why does ethnic diversity undermine public goods provision? Am. Political Sci. Rev. 2007, 101, 709-725. [CrossRef]

66. Wimmer, A.; Cederman, L.A.; Min, B. Ethnic politics and armed conflict. A configurational analysis of a new global dataset. Am. Sociol. Rev. 2009, 74, 316-337. [CrossRef]

67. Wendling, Z.A.; Emerson, J.W.; Esty, D.C.; Levy, M.A.; de Sherbinin, A. 2018 Environmental Performance Index; Yale Center for Environmental Law \& Policy: New Haven, CT, USA, 2018. 